\title{
Inventáře hudební sbírky v Blížkovicích na Moravě \\ z 18. a 19. století a jejich srovnání se současným stavem pramenů
}

\section{The Inventories of the Music Collection in Moravian Blížkovice from 18th and 19th Century and the Comparison with the Current State of the Preserved Sources}

Michaela Ratolístková / mratolistkova@mzm.cz

Department of the History of Music, Moravian Museum; Department of Musicology, Faculty of Arts, Masaryk University, Brno, CZ

\begin{abstract}
The musical collection from St. Bartholomew's Church in Moravian Bližkovice is a set of compositions enabling us to better understand the musical culture of a small city in eighteenth century. The highly interesting aspects of the collection are a large number of compositions with Czech lyrics and the structure of the collection itself, including vocally-instrumental compositions, a large number of concertos, sinfonias and partitas. The dating of the scores vary from the beginning of the eighteenth century to the half of the nineteenth century. The owners of the compositions were in most of the cases local cantors - Severin Josef Weiser, Antonín Ignác Jan Krimer, Antonín Sigisbert Krimer and Gustav Erben. The three included transcripts of inventories are helping to increase an insight into the completeness of the collection by mentioning the unpreserved compositions and thus exposing a nearly complete image of the contemporary local musical production.
\end{abstract}

\section{Keywords}

Moravia, Blížkovice, music collection, inventory, church music, cantilena, aria, marian antiphons, Krimer, Weiser, Erben

Předložená práce vznikla za finanční podpory Ministerstva kultury $v$ rámci institucionálního financování na dlouhodobý koncepční rozvoj výzkumné organizace Moravského zemského muzea (DKRVO, MK000094862). 
Historické inventáře jsou cenné dokumenty, díky nimž je často možné rekonstruovat původní strukturu hudebních fondů. Mnohdy obsahují nejen výčty skladeb a autorů, ze kterých je možné určit dobové zařazení hudebnin, ale zaznamenávají i další informace, jako jsou hudební incipity kompozic, jejich obsazení, přesná datace či bližší určení provenience. Sbírky Oddělení dějin hudby Moravského zemského muzea (dále jen ODH MZM) uchovávají vyjma hudebnin i množství takových inventářů, mezi nimiž jsou tři náležející k fondu z kostela sv. Bartoloměje v Blížkovicích na Moravě. Hudebniny jsou zde uloženy pod signaturami A 3744-3901, inventáře pak pod signaturou G 28a-c. Blí̌̌kovická sbírka dosud nebyla v literatuře výrazně reflektována, ${ }^{1}$ častěji jsou zmiňováni př́slušníci zde působící kantorské rodiny Krimerů, ${ }^{2}$ nicméně souhrnná studie na toto téma prozatím chybí. Cílem tohoto textu je srovnání zmíněných hudebních inventářủ se stavem do současnosti dochovaných hudebnin.

Bližkovická sbírka je poměrně ojedinělým souborem odrážejícím hudební provoz v 18. století v rámci malé vesnické farnosti. Neobvyklý je zvláště počet skladeb s českými texty, které se zde vyskytují. Celkově je nyní dochováno 159 kompozic, ${ }^{3}$ přičemž ve všech př́padech se jedná o rukopisy vyjma jednoho tisku z 19. st. Časový rozsah hudebnin se pohybuje od roku 1700 do první poloviny 19. století. Nejstarší část sbírky pochází většinou z majetku kantora Severina Josefa Weisera. Kompozice nejpozději od 40. let 18. století vlastnil Antonín Ignác Jan Krimer a další členové jeho rodu. Poslední, nejmladší část sbírky, zahrnující hudbu 19. století, je hlavně dědictvím Gustava Erbena. Tato studie nepojednává o životních osudech majitelů hudebnin, nicméně vzhledem k nutnosti časového rozlišení sbírky i obsahu inventáře zde nyní uvedeme stručná známá data výše zmíněných majitelů a opisovačů.

Severin Josef Weiser ${ }^{4}(1683-1756)$ působil v Rosicích, ${ }^{5}$ od roku 1713 pak jako učitel na farní škole v Martínkově. ${ }^{6}$ Následně se přesunul kolem roku 1726 do Blí̌zovic, kde působil jako „ludi magister" až do své smrti v roce 1756. Dle přípisu v úmrtní matrice

1 Nejobsáhlejší studií zabývající se hudební sbírkou, inventáři i kantorskou rodinou Krimerů je text Karla Cikrleho ze 70. let 20. století Kantorská hudba na kưru v Moravských Budějovicích a Bližkovicích, který ovšem nebyl publikován. Text byl původně součástí diplomové práce a v roce 1971 měl být vydán ve sborníku Monumenta Moraviae. Publikace sborníku se nakonec bohužel neuskutečnila. Navazující výzkum týkající se zvláště rodiny Krimerů a kantorů provádí v současné době Petr Hlaváček. Za laskavé poskytnutí těchto textů a poznámek děkuji jejich autorům. Z vydaných textů vztahujících se přímo ke sbírce: MALÝ, František. Blížkovická hudební sbírka. In Časopis moravského muzea, Brno, roč. 70, 1985, s. 201-210.

2 Heslo Krimer in ČERNUŠÁK Gracian - ŠTĚDROŇ, Bohumír - NOVÁČEK, Zdenko. ČSHS. Praha: Státní hudební nakladatelství, 1963, s. 750; TROJAN, Jan. Kantoři na Moravě a ve Slezsku. Brno: Muzejní a vlastivědná společnost v Brně, 2000, s. 208; SEHNAL, Jiří - VYSLOUŽIL, Jiří. Dějiny hudby na Moravě. Brno: Muzejní a vlastivědná společnost v Brně, 2001, s. 59, 64. Dále viz soupis literatury.

3 Inventárních čísel je pouze 158. Skladbou navíc je neinventované anonymní Rorate Coeli vložené v signatuře A 3819.

4 Psán také jako Weisner či Weyser.

5 HLAVÁČEK, Petr. Kantoři na Moravě a ve Slezsku. Online databáze. Dostupné z: http://cantores.wz.cz/ jmen/w/weiser_sev.html

6 PADRNOSOVÁ, Jitka. Školství. In NEKUDA, Vladimír. Moravskobudějovicko, Jemnicko. Brno: Muzejní a vlastivědná společnost v Brně, 1997, s. 426. 
Blížkovic byl učitelem v Blížkovicích soustavně celých 30 let. V současné době je ve sbírce dochováno 9 skladeb z jeho vlastnictví. ${ }^{7}$

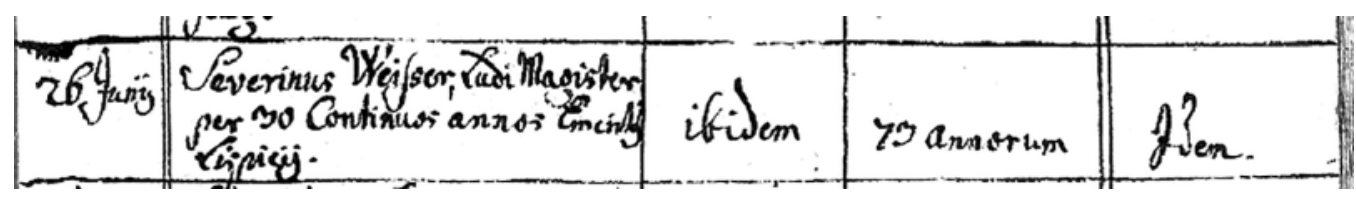

Obr. 1 Záznam o smrti Severina Josefa Weisera z blížkovické úmrtní matriky 1735-1785.

Antonín Ignác Jan Krimer ${ }^{8}$ (1707-1769) se narodil 2. července 1707 v Moravských Budějovicích, ${ }^{9}$ kde také působil jako kantor. O jeho životě zatím není mnoho známo, ${ }^{10}$ nicméně byl majitelem největšího počtu hudebnin, které se dochovaly v blížkovické sbírce (111 kusů). V některých zdrojích je jeho datum narození zaměňováno s datem narození jeho syna Antonína Sigisberta Krimera a následně chybně uvedeny i jejich životní osudy. Hudebnina s př́ípisem: „Ex rebus Antonij Ignatij Joannis Krimer“ je však datována již do roku 1742, není tedy možné, že by se jednalo o Antonína Sigisberta, který se narodil r. 1740 .

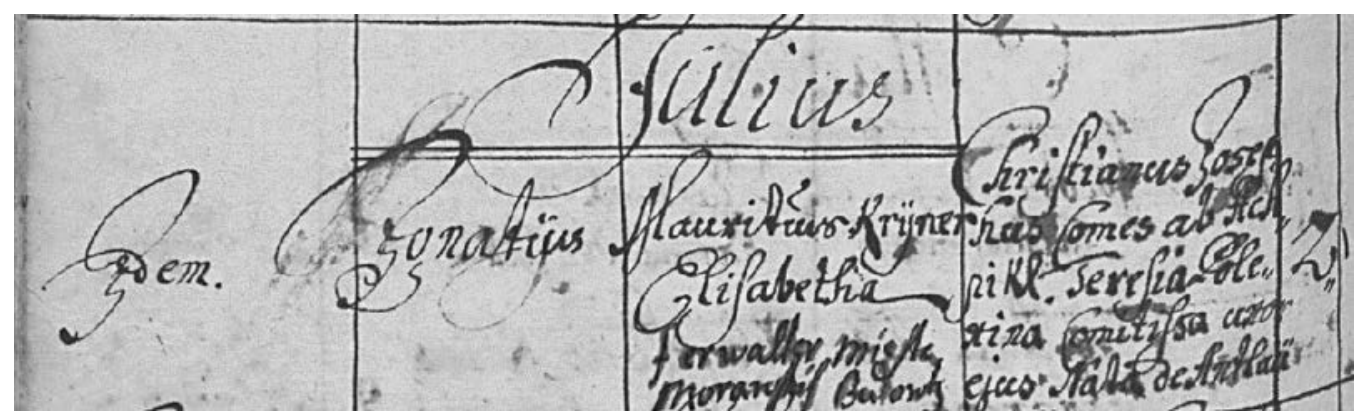

Obr. 2 Záznam o narození (Antonína) Ignáce (Jana) Krimera z moravskobudějovické matriky narozených 1677-1771.

Antonín Sigisbert Krimer (1740-1797) se narodil 7. prosince 1740 v Moravských Budějovicích. ${ }^{11}$ Roku 1762 přešel jako učitel do Blížkovic, kde se také oženil a působil zde až do své smrti. S sebou zřejmě vzal i otcovu hudební sbírku. Sám pak některé

7 MZA Brno, E 67, signatura 13415, s. 203. Dostupné online: http://actapublica.eu/matriky/brno/prohlizec $/ 1088 /$ ?strana $=274$

8 Uváděn i jako Krimmer, nicméně na hudebninách (z nichž většinu považujeme za autografy) je uveden pouze jako Krimer, tedy volíme tento tvar zápisu příjmení, a to v případě obou Krimerů.

9 MZA Brno, E 67, signatura 10660, s. 162. Dostupné online: http://actapublica.eu/matriky/brno/prohlizec/7278/?strana $=162$

10 Více informací přinese připravovaná studie P. Hlaváčka.

11 MZA Brno, E 67, signatura 10660, s. 358. Dostupné online: http://actapublica.eu/matriky/brno/prohlizec/7278/ 
hudebniny také opatřoval, což můžeme vyčíst z přípisů na notách. Dnes je dochováno 7 skladeb z jeho majetku.

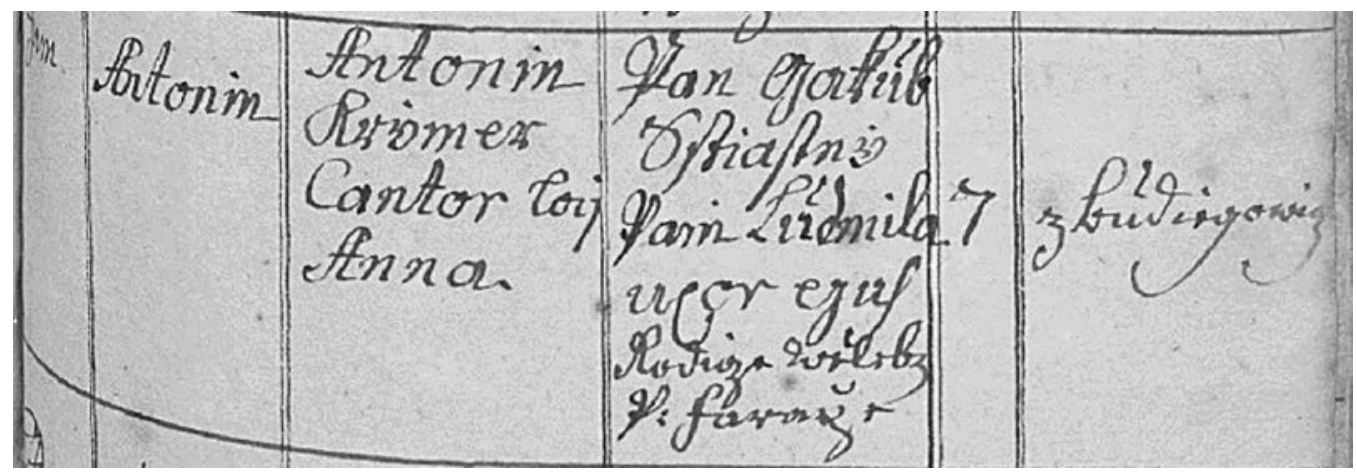

Obr. 3 Záznam o narození Antonína (Sigisberta) Krimera z moravskobudějovické matriky narozených 1677-1771.

Gustav Erben byl majitelem nejmladší části sbírky, spadající převážně do první třetiny 19 . století. O jeho osobě v tuto chvíli není nic bližšího známo, nicméně dle přípisu na anonymní Misse B dur opatřoval noty př́mo pro kostel: „Von Gustav Erben der Lispitzer Pfarr Kirche gespendet Am 1 Februar 1832“. Zda tyto skladby i sám komponoval nelze posoudit. Dochováno je 23 kompozic z jeho majetku.

Nejstarší část sbírky představuje Weiserovu hudební pozůstalost. Hudební materiál Antonína Ignáce Jana Krimera byl pořizován pro jeho působiště v Moravských Budějovicích, do Blížkovic se přestěhoval až s jeho synem Antonínem Sigisbertem. Ten převzal patrně celou otcovu pozůstalost (Antonín Ignác Jan většinu svých hudebnin opatřil pořadovými čísly a ta na sebe většinou navazují i na nyní dochovaných hudebninách, navíc ve sbírce z Moravských Budějovic se žádné Krimerovy hudebniny nevyskytují) a rozšiříi ji o nové skladby. Nezodpovězenou otázkou ovšem je, kdy Antonín Sigisbert sbírku získal. Zdá se, že to muselo být až po smrti jeho otce, tedy roku 1769. Do té doby si zřejmě vystačil s kompozicemi, které již na blížkovickém kưru byly, př́ípadně v té době mohl opatřit těch několik skladeb, na nichž je jako majitel podepsán.

Většinu dochovaných kompozic ve sbírce je možné přiřadit výše zmíněným majitelům, jelikož obvykle nesou označení vlastníka. Další je možné zařadit do jejich majetku na základě shodných znaků, jako je rukopis či - zvláště v př́ípadě Krimerových skladeb - také jejich číslování. I tak se zde nachází několik kompozic, jejichž majiteli byly neznámé osoby. Mezi ty patří nejstarší datovaná kompozice sign. A 3759 anonymní $O$ bitter Todt ich muss ins Grab, kterou vlastnil Joseph Franz Pohl, „Ludi Rectoris et Organistae Pro Tempore Pirnitz“, jenž byl kolem roku 1724 rektorem brtnické školy. ${ }^{12}$ Skladba byla zapsána už 5 . března 1717, není tedy jasné, zda ji pro kůr získal Severin Josef Weiser nebo ji pořídil v Moravských Budějovicích Krimer st. Vzhledem k tomu, že skladba byla

12 KOURKOVÁ, Lucie. Pamětni kniha městečka Brtnice z 18. století. Diplomová práce. Jihočeská univerzita v Českých Budějovicích, vedoucí práce doc. PhDr. Josef Hrdlička, Ph.D., 2011, s. 42. 
dodatečně opatřena jeho pořadovým číslem a poté zřejmě i zanesena v inventáři, můžeme soudit, že byla součástí blížkovického hudebního provozu, a to nezvykle dlouho, více než 70 let. ${ }^{13}$ Stejně tak sign. A 3778, anonymní sekvence ke svátku Božího těla Lauda Sion, která dle rukopisu patří spíše mezi nejstarší část sbírky. Dochované hlasy vypadají, že pochází z počátku 18. století, nicméně part varhan byl evidentně dopsán (zřejmě pro špatnou kvalitu původního partu) až kolem poloviny 18. století; rukopis je velmi podobný dalším Krimerovým hudebninám. Noty byly tedy zřejmě stále použivány. Žádné bližší údaje o majiteli či provenienci ovšem nelze vyvodit. Do první třetiny 18. st. spadá ještě anonymní Requiem und Todtenlieder, sign. A 3885, které nenese žádné bližší identifikační znaky. Další z hudebnin, které není možno přiřadit, je anonymní Offertorium de Joanne Nepomuceno, sign. A 3838, jehož majitel je označen pouze iniciálami J. H. Skladba má sice jisté inventární číslo, nicméně to neodpovídá Krimerovu číslování hudebnin. Stejně tak není možné nikomu přiřadit Rathgeberovo ${ }^{14}$ Verbo Domini sign. A 3888 ani jedinou instrumentální skladbu sbírky, anonymní Casatio sign. A 3900. Z dochované pramenné základny vyplývá, že obě pravděpodobně byly součástí Krimerovy sbírky. K zajímavostem fondu patří také Salve Regina sign. A 3755, kde je jako autor uveden „Auth. Sig. Krimer“. Dochován je pouze titulní list a part varhan, nicméně tato kompozice potvrzuje domněnku, že někteří členové rodu Krimerů skladby nejen opatřovali, ale i upravovali či komponovali vlastní. ${ }^{15}$ Nelze však bohužel dovodit, o kterého z Krimerů se jedná.

Pokud bychom tedy chtěli zařadit dnes dochovaných 159 hudebnin mezi výše uvedené kantory, výsledek bude následující:

\begin{tabular}{|c|c|c|c|c|c|c|}
\hline $\begin{array}{c}\text { Severin Josef } \\
\text { Weiser }\end{array}$ & $\begin{array}{c}\text { Antonín Ignác } \\
\text { Jan Krimer }\end{array}$ & $\begin{array}{c}\text { Antonín Sigis- } \\
\text { bert Krimer }\end{array}$ & Gustav Erben & \multicolumn{3}{|c|}{ Nezařazené } \\
\cline { 4 - 7 } & & & $\begin{array}{c}\text { 1. třetina } \\
18 . \text { st. }\end{array}$ & $\begin{array}{c}\text { Kolem r. } \\
1750\end{array}$ & $\begin{array}{c}\text { Po roce } \\
1800\end{array}$ \\
\hline 9 & 111 & 7 & 23 & 3 & 5 & 1 \\
\hline
\end{tabular}

Obraz původního rozsahu sbírky můžeme rekonstruovat na základě tří inventářo̊, které se v rámci blížkovického fondu nyní nacházejí. ${ }^{16}$ Dva pocházely z konce 18 . století, třetí byl mladší, vznikl asi až v první polovině 19. století. Ve všech případech se dnes jedná o opisy, které pořídil zřejmě ve 20. letech 20. století Robert Smetana, ${ }^{17}$ úpravy a drobné poznámky provedl roku 1929 Vladimír Helfert. Originály inventářů dnes s největší pravděpodobností již neexistují (tento fakt zmiňuje v nevydaném textu k Blížkovicím

13 Což dokládá její zápis v inventáři ještě na konci 18. st.

14 Na notách je kompozice označena jako anonymní, autor byl dohledán pomocí databáze RISM.

15 Srov. MALÝ, op. cit., s. 206.

16 Srov. RACEK, Jan. Hudební inventáře a jejich význam pro hudebněhistorické bádání. Časopis moravského musea. Vědy Společenské, roč. 47, 1962, s. 135-162.

17 Robert Smetana byl mezi lety 1924-1932 zaměstnancem tehdejšího Hudebního archivu Moravského zemského muzea, vyjma opisů blížkovických inventář zpracoval i soupis hudebnin premonstrátského kláštera v Nové Ř́rsi. 
i Karel Cikrle již v 70. letech 20. století). V rámci zpracování této studie byly použity pouze Smetanovy opisy, v popisu inventáře vycházíme z jím zaznamenaných údajů. ${ }^{18}$

Nejdůležitějším z inventářů je první z nich, pořízený roku 1797 (sign. G 28a). Autorem byl nově nastupující kantor Ignác Trnka, který v Bližkovicích působil až do své smrti v roce 1831. Inventár byl zapsán na tuhém papíre o velikosti 210 x $340 \mathrm{~mm}$, celkem o 8 foliích. Již v názvu je uvedeno, že se jedná o soupis hudebnin Antonína Krimera, darovaných kostelu v Blížkovicích: Registerium / Partium Musicalium ab Antonio Krimmer Ecclesiae Lispicensis donatarium / et novo Ludi rectori immannatarum Ignatio Trnka die $12^{\text {mo }}$ Januarij $1797 .{ }^{19}$

Jednotlivé rubriky, jejichž obsah je číslován římskými číslicemi, uvádí vždy název skladby a autora či majitele hudebniny, a to v následujícím pořadí: Missae (Nro. I-XXXVI), Pastorellae (Nro. I-VII), Rorate (Nro. I-IV), Lytaniae (Nro. I-XXIII), Miserere omnia in folio (Nro. I-IV), Offertoria ${ }^{20}$ (Nro. I-XXXXVI), následující rubriky již neobsahují seznamy skladeb, uvádí pouze jejich celkový počet: Asperges $1^{m o}$, Pangelingua 2, Veni S. Spiritus 2 / Cantilenae et Ariae de Adventu atque Pastoralis XIX / Cantilenae, et Mottetae pro defunctis, et funebris XXVI / Ariae Diversae: Salve: Alma, Regina Coeli 18 / Cantilenae variae 24.

Na konci inventáře je poznámka víceméně opakující údaj z titulní strany: Inventarium / Jener Musikalien / die Anton Krimer / Lispitzer Schullehrer seinem nachfolgen / Ignatz Trnka / über geben.

Vzhledem k tomu, že inventář vznikl de facto jako pozůstalostní, vycházel autor (žrejmě Trnka) z původního číslování, kterým opatř̌ili své hudebniny Krimerové, a záznamy tedy většinou číslováním odpovídají. U sporných kompozic je možné vyjít z názvu skladby, který je uveden vždy, následuje uvedení autora nebo majitele, které se neřídí žádným pravidlem. Většinou jsou jménem majitele doplněny anonymní skladby, nicméně toto pravidlo není stoprocentní.

V rubrice Missae je celkem 34 záznamů, z nichž můžeme dnes ve fondu nalézt pouze 8 kusů hudebnin..$^{21}$

Následující rubrika Pastorellae obsahuje 7 záznamů, ke kterým bohužel není možné přiřadit s jistotou žádnou hudebninu. U žádné z dochovaných pastorel se totiž neshoduje jiný údaj, než je historické inventární číslo, z čehož není možné vycházet.

Soupis pokračuje čtyřmi Rorate, z nichž dosud se ve sbírce nacházejí 3 kusy: Nro. II. sign. A 3844, Nro. III. sign. A 3835, a Nro. IV. sign. A 3842. Navíc je dochováno ještě

18 V rámci př́ípravy tohoto textu proběhla opětovná snaha o dohledání originálů inventářů, a to jak autorkou textu, tak Vladimírem Maňasem, kterému patří můj srdečný dík. Byly kontaktovány všechny instituce vlastnící archivní fondy týkající se obce Blí̌zovice: SOkA Třebíč, pracoviště v Moravských Budějovicích, SOkA Znojmo a Diecézní archiv Biskupství brněnského. Žádný z těchto archivů však inventáře neuchovává, originály inventářủ je tedy skutečně nutno považovat za ztracené.

19 Srov. MALÝ, op. cit., s. 203.

20 Nadpis rubriky není uveden.

21 Uvádíme vždy původní číslo inventáře a novou signaturu ODH MZM: I.-XVII. -, VVIII. A 3862, XVIV. -, XX. A 3826, XXI.-XXIV. -, XXV. A 3786, XXVI. -, XXVII. A 3825, XXVIII. A 3824, XXIX.-XXX. -, XXXI. A 3883, XXXII. A 3847, XXXIII. -, XXXIV. A 3823. 
jedno Rorate Caeli, které nemá žádné číslo a bylo omylem zařazeno do jiné kompozice Litanií Antona Schimana sign. A 3819.

Litaniae obsahují 23 záznamů, v blí̌̌kovickém fondu se dnes nachází vyjma jediné skladby všechny. ${ }^{22}$

Z původního počtu čtyř Miserere se dnes ve sbírce nalézají pouze dvě: Nro. II. sign. A 3793, a Nro. III. sign. A 3792.

Soupis pokračuje Offertorii, která jsou počtem 47 skladeb nejrozšířenějším druhem kompozic, dochováno je 35 kusů...$^{23}$ Anonymní Offertorium de Resurrectione sign. A 3787, které bezpochyby pochází z Krimerova majetku, dokládá používání tohoto hudebního materiálu ještě v polovině 19. století. Jednalo se zřejmě o oblíbenou skladbu, kterou dle datace na obalu hudebniny v roce 1831 využíval tehdejší kantor. Gustav Erben v té době vyhotovil i nový obal, nicméně ten musel být přesnou kopií originálu, protože uvádí nejen původní ćíslování, ale i Krimera jako majitele hudebniny.

Poslední částí inventáře je již uvedený souhrn menších skladeb, které tvoří tzv. „cantileny“", árie, Reginae coeli etc. Tyto rubriky bohužel neuvádějí seznam, pouze souhrnný počet obsažených kusů, což značně znesnadňuje jejich určení. I přesto však bylo částečně možno tuto část rekonstruovat, což uvádíme v tabulkách níže (pokud je to možné). $\mathrm{V}$ tomto případě přidáváme podrobnější údaje o skladbách, tak aby odpovídaly podobě předchozích částí inventáře.

\section{Asperges, Pange lingua, Veni S. Spirtus (5)}

V současném blížkovickém fondu je z této skupiny dochováno pouze jediné Asperges me anonymního autora sign. A 3765. Jeho majitelem byl Antonín Ignác Jan Krimer a skladba byla vyjma textu Hysopo et mundobor opatřena ještě dodatečně verši Altare alleluja.

2. Cantilenae et Ariae de Adventu atque Pastoralis (19)

Tuto část bylo možné rekonstruovat kompletně, navíc ve sbírce se nachází další dvě árie, které na číslování navazují (jsou uvedeny na konci soupisu kurzivou), ale z nějakého důvodu nebyly do inventáře zahrnuty, a také je zde ještě jedna nečíslovaná Cantilena Bohemica (Ježižs, Maria, Josef) sign. A 3891 z majetku A. I. J. Krimera, která ovšem nemá žádné číslo. Můžeme uvažovat o tom, že se jednalo o Nro. 20 v inventáři, což však nelze s jistotou určit.

Zdrojem textů vánočních skladeb jsou převážně české barokní kancionály - Božanův Slavíček rájský, Kancionál Český M. Šteyera, Rovenského Capella regia musicalis, ale i poezie Adama Michny z Otradovic. Identifikaci skladeb provedl ve své studii F. Malý. ${ }^{24}$

22 I. A 3813, II. A 3814, III. A 3817, IV. A 3800, V. -, VI. 3818, VII. A 3819, VIII. A 3808, IX. A 3865, X. A 3866, XI. A 3807, XII. A 3809, XIII. A 3828, XVI. A 3816, XVII. A 3803, XVIII. A 3812, XX. A 3801, XXI. A 3804, XXII. A 3810, XXIII. A 3811.

23 I. A 3829, II. A 3860, III.-VI. -, VII. A 3850, VIII. A 3858, IX. A 3787, X. A 3852, XI. A 3833, XII. A 3832 , XIII. A 3831, XIV. A 3830, XV. A 3843, XVI. A 3897, XVII. A 3849, XVIII.-XIX. -, XX. A 3853, XXI. A 3856, XXII.-XXIV. -, XXV. A 3857, XXVI. A 3859, XXVII. A 3805, XXVIII. A 3868, XXIX. A 3820, XXX. A 3822, XXXI. A 3815, XXXII. A 3899, XXXIII. A 3848, XXXIV. A 3851, XXXV. A 3839, 36. A 3864, 37. -, XXXVIII. A 3863, XXXVIIII. A 3861, 40. A 3864, 41. A 3806, 42. A 3854, 43. A 3855, XXXXV. -, XXXXVI. A 3895.

24 MALÝ, op. cit., s. 205. 
Jak také upozorňuje, většina kompozic přebírá pouze textovou předlohu, zatímco melodie jsou zkomponovány nově, aniž by respektovaly původní nápěv.

\begin{tabular}{|c|c|c|c|c|}
\hline Nro. & Autor & Název & Majitel $^{25}$ & Signatura \\
\hline I. & $x$ & De Adventu (Maria plna milosti) & AIK & A 3774 \\
\hline III. & $x$ & Aria de Adventu (Nowinu poslouchejte) & AIK & A 3770 \\
\hline III. & $x$ & De Adventu (Zdrawas Panno czista) & AIK & A 3777 \\
\hline IV. & $\mathrm{x}$ & De Adventu (Pozdrawena bud') & AIK & A 3775 \\
\hline V. & $x$ & Cantus Adventualis (Hle přijde Pán) & AIK & A 3776 \\
\hline VI. & $\mathrm{x}$ & Pastorella Natalis (Do Bethlema) & AIK & A 3744 \\
\hline VII. & $\mathrm{x}$ & Pastorella Boemica (Jasné Sluncze již jest wišlo) & AIK & A 3745 \\
\hline VIII. & $x$ & Cantilena de Nativitate (Huc ad Regem) & AIK & A 3751 \\
\hline IX. & R.P. Novak & Pastorella Natalitia (Wtieleny Bože) & AIK & A 3758 \\
\hline $\mathrm{X}$ & $\mathrm{x}$ & Pastorella de Nativitate (Huc coridon) & AlK & A 3756 \\
\hline $\mathrm{XI}$. & $x$ & De nativitate Domini (Huc ad Regem) & SJW & A 3768 \\
\hline XII. & $x$ & $\begin{array}{l}\text { Cantillena Pastorica 1ma (Wo Wanoczich) / } \\
\text { Secunda de Resurrectione (Na bubny, trouby) }\end{array}$ & ASK & A 3757 \\
\hline XIII. & $x$ & Cantilena de Nativitate (Toto male dietatko) & AIK & A 3779 \\
\hline XIV. & $\mathrm{x}$ & Cantilena de Nativitate (O ditie roztomile) & AIK & A 3873 \\
\hline $\mathrm{XV}$. & $\mathrm{x}$ & Pastorella de Nativitate (Hey hey pastuškove) & AIK & A 3878 \\
\hline XVI. & $x$ & Cantilena de nativitate (Sem podte pastyři) & AIK & A 3879 \\
\hline XVII. & $x$ & Pastorella (Nowinu radostnou zwiste) & AIK & A 3880 \\
\hline XVIII. & $x$ & Pastorella de Nativitate (Hey hey czo se stalo) & SJW & A 3878 \\
\hline XIX. & $x$ & Pastorella de Nativitate (Pane Jezu) & AIK & A 3746 \\
\hline$X X$ & - & - & - & - \\
\hline$X X I$. & $x$ & Pastorella de Nativitate & $A I K$ & A 3845 \\
\hline XXII. & $x$ & Pastorella Böemica (Poslechniete mnie malo) & SJW & A 3843 \\
\hline
\end{tabular}

3. Cantilenae et Mottetae pro defunctis et funebris (23)

Tuto rubriku bylo možné zrekonstruovat jen částečně, z původních 23 záznamů lze s jistotou přiřadit pouze 13 . Současně se ve sbírce dochovaly navíc další 4 skladby se stejným typem duchovních textů, které ovšem do sezamu nelze včlenit. Jedná se většinou o skladby, které nemají žádné pořadové číslo: Anonymní Aria pro defunctis A 3766, Cantilena de Passione (Placzte anjelove) sign. A 3767, obě anonymní a z majetku A. I. J. Krimera. $\mathrm{Z}$ pozůstalosti jeho syna Antonína Sigisberta sem navíc spadá Cantus de funebris sign. A 3892, taktéž bez uvedení autora. Poslední je cantilena nebo aria Wsiczkni ze swieta musime sign. A 3784 bez označení majitele, pocházející přibližně z poloviny 18. století.

České texty byly opět převzaty povětšinou z českých barokních kancionálů.

\begin{tabular}{|l|l|l|l|l|}
\hline Nro. & Autor & Název & Majitel & Signatura \\
\hline I. & - & - & - & - \\
\hline II. & $\mathrm{x}$ & Cantilena pro Defuncte (Odpoczinuti wieczne) & AIK & A 3782 \\
\hline III. & $\mathrm{x}$ & Cantus Böemicus pro defunctis (Swietska marnost) & AIK & A 3875 \\
\hline
\end{tabular}

25 Uvedeny jsou pouze iniciály: AIK = Antonín Ignác Jan Krimer, ASK = Antonín Sigisbert Krimer, SJW = Severin Josef Weiser. 
Inventáře hudební sbírky v Blížkovicích na Moravě z 18. a 19. století ...

\begin{tabular}{|c|c|c|c|c|}
\hline Nro. & Autor & Název & Majitel & Signatura \\
\hline IV. & $x$ & $\begin{array}{l}\text { Cantilena Boemica pro defunctis (Odpoczintež v po- } \\
\text { koji) }\end{array}$ & AIK & A 3874 \\
\hline V. & $x$ & Cantilena pro defuncte (Cur mundus militat) & AIK & A 3872 \\
\hline VI. & O. Lamb & Todten Lied & $\begin{array}{l}\text { AIK/ } \\
\text { ASK }^{26}\end{array}$ & A 3781 \\
\hline VII. & $x$ & Todten Gesang (Ach Du mein tausend liebster Gott) & AIK & A 3893 \\
\hline VIII. & $x$ & Cantilena Boemica pro Defunctis (Smilujte se) & AIK & A 3754 \\
\hline IX. & $x$ & Beru se od was przatele & AIK/ASK & A 3783 \\
\hline $\mathrm{X}$. & $\mathrm{x}$ & Cantilena pro defuncte (O labilis res) & AIK & A 3773 \\
\hline $\mathrm{XI}$. & $x$ & Cantilena Bohemica pro Defunctis (Smilujte se) & AIK & A 3869 \\
\hline XII. & - & - & - & - \\
\hline XIII. & $x$ & Cantilena pro Defuncte (Parce mihi Domine) & AIK & A 3877 \\
\hline XIV. & - & - & - & - \\
\hline $\mathrm{XV}$. & $x$ & O bitter Todt & Pohl & A 3759 \\
\hline $\mathrm{XVI}$. & - & - & - & - \\
\hline XVII. & $\mathrm{x}$ & Cantus Böemicus pro defunctis (Swiedska marnost) & AIK & A 3875 \\
\hline XVIII.-XXIII. & - & - & - & - \\
\hline
\end{tabular}

4. Ariae diversae: Salve, Alma, Regina Coeli (18)

V celé sbírce jsou dnes dochovány pouze tři mariánské antifony, odpovídající této rubrice. Salve Regina sign. A 3755, jehož autorem by měl být dle př́ípisu na obalu některý z Krimerů, Alma Redemptoris Valentina Rathgebera sign. A 3769 a Ave Regina sign. A 3763. Tato jediná skladba je prokazatelně z majetku Antonína Ignáce Jana Krimera a nese podnázev Ave Regina Caelorum vel Regina Caeli Aria de Tempore.

5. Cantilenae variae (24)

Kompozice z této rubriky mají jako jediné specifické číslování, odlišné od předchozího. Zařadit se podařilo pouze 6 skladeb. Sedm kompozic, odpovídajících dané rubrice, zařadit do seznamu nejde kvůli chybějícím informacím na obalech. Mezi ty patří anonymní Cantilena Germanica sign. A 3780, Aria de Tempore (O Deus ergo amo) sign. A 3870 , Cantilena pro Festivitate ( $W$ den slawny pamatku jeho obnovujem) sign. A 3876, vše z majetku A. I. J. Krimera; Aria de quocunque Sancto (Milý swatý Floriane / Swaty Jene Nepomuczky) a Cantilena de Venerabili sign. A 3762 z majetku Antonína Sigisberta Krimera sign. A 3894 a Rathgeberovo Verbo domini (sign. A 3888).

26 Hudebnina nemá obal, ale je opatřena pořadovým číslem. Není však možné rozhodnout, který z Krimerů byl vlastníkem. 


\begin{tabular}{|l|l|l|l|l|}
\hline Nro. & Autor & Název & Majitel ${ }^{27}$ & Signatura \\
\hline N. 1 & $\mathrm{x}$ & $\begin{array}{l}\text { Cantilena de Venerabili (Zdraw bud' předobry Je- } \\
\text { žíši) }\end{array}$ & AIK & A 3750 \\
\hline N. ${ }^{28}$ & $\mathrm{x}$ & Cantilena de Venerabili (Zawitej k nám o Welebna) & AIK & A 3753 \\
\hline N. 2 & $\mathrm{x}$ & Cantilena de Venerabili (K stolu Božímu) & AIK & A 3749 \\
\hline N. 3 & $\mathrm{x}$ & Arie de Venerabili (Sem růže lilia) & AIK & A 3772 \\
\hline N. 4 & $\mathrm{x}$ & Cantilena Czeska O Welebne Swatosti & AIK & A 3764 \\
\hline N. 5 & $\mathrm{x}$ & Cantilena de Venerabili (O spasytedlna hostie) & AIK & A 3771 \\
\hline N. 6 & Authore aliquo Italo & Concertus Lauda Syon de Venerabili Sacramento & AIK & A 3752 \\
\hline
\end{tabular}

Poslední poznámka v inventáři, která však byla připsána kolem poloviny 19. století, se týká nastupujícího nového kantora, kterým byl Tomáš Vybíral. Převzetí zděděných Trnkových hudebnin zanesl do soupisu v souladu s předchozí praxí. ${ }^{29}$

Blížkovická sbírka je pozoruhodná množstvím skladeb s českými texty (více než čtvrtina sbírky), kterých je zde nejvíce zvláště v rámci výše uvedených cantilen a árií s různými duchovními texty. Největší zastoupení mají anonymní kompozice, nicméně jména autorů u neanonymních hudebnin odráží poměrně obvyklé složení repertoáru, zvláště kolem poloviny 18. století. Nalézáme zde (převážně tedy v záznamech inventáře) kompozice Jana Josefa Ignáce Brentnera, Šimona Brixiho i jeho syna Františka Xavera Brixiho, Františka Ignáce Tůmy, Václava Jana Kopřivy, Valentina Rathgebera, Františka Antonína Míči, ale i autory zřejmě pouze lokání - Jiří Kvasnička či Novotný. ${ }^{30}$

Inventář sign. G 28a je nejdůležitějším zdrojem vztahujícím se k blí̌zovické sbírce, protože reflektuje i její nedochovanou část. Oproti tomu inventář sign. G 28c, který pochází až z poloviny 19. století, takřka odpovídá současnému stavu hudebnin. ${ }^{31}$ Částečně respektuje řazení rubrik, které ovšem neodděluje, i číslování hudebnin, ale kompozic celkově uvádí mnohem méně než sign. G 28a. Můžeme se tedy domnívat, že v 19. století byly některé neaktuální hudebniny vyřazeny a ty, které jsou v tomto inventáři zaneseny, se z velké části dochovaly dodnes a tvoří současný blížkovický fond. Hudebniny musely být vyřazeny již předtím, než je získal nadučitel a ředitel kůru Paulín Vybíral, který jejich převzetí potvrzuje přípisem na konci. O to zajímavější je zjištění, že i v tomto soupisu se stále udržují Weiserovy skladby, tedy hudebniny, které byly aktuální o sto let dříve. Jedná se např́íklad o Cantilenu de Nativitate Domini (Huc ad Regem) sign. A 3768. Z neznámého důvodu jsou také dnes v blížkovické sbírce skladby, které ovšem v tomto inventáři zaznamenány nejsou (jedná se o přibližně tři desítky kompozic. Při vzniku inventáře mohly být například uloženy na jiném místě a k ostatním hudebninám navráceny později.

27 Uvedeny jsou pouze iniciály: AIK = Antonín Ignác Jan Krimer, ASK = Antonín Sigisbert Krimer, SJW = Severin Josef Weiser.

28 Zde došlo v číslování $\mathrm{k}$ dobové chybě.

29 Vorstehende Musikalien sind dem Nachfolger des Ignaz Trnka Thomas Wijbiral übergeben worden.

30 Bez určení křestního jména.

31 Seznam / skladeb hudebnich při chrámu páně sv. Bartolomĕje / v Bližkovicích se nalézajicích. Žádná datace uvedena není. 
Dosud ještě nebyl zmíněn inventář G 28b. Ten byl pořízen roku 1789 Ignácem Trnkou, ${ }^{32}$ a od předchozích dvou je zcela odlišný. Je zapsán na 7 foliích o velikosti $210 \mathrm{x}$ 340 mm. Postrádá vnitřní členění jednotlivých rubrik, hudebniny jsou zapisovány poměrně nahodile, číslování střídá římské i arabské číslice. Nesmírně zajímavý je obsah inventáře - obsahuje-li o rok starší soupis sign. G 28a převážně repertoár typický pro menší kůry v polovině 18. století a odráží-li alespoň částečně dochovanou sbírku, inventář sign. G 28b zahrnuje jména nejznámějších skladatelo̊ dané doby a navíc se současným stavem blížkovické sbírky neexistuje žádné spojení. Tento soupis zahrnuje převážně duchovní árie ${ }^{33}$ dueta a moteta, ale současně i množství instrumentální hudby jako jsou sinfonie, partity či koncerty. Z dosud dochovaných skladeb nelze ani jednu z nich identifikovat pokud bychom uvažovali nad tím, že alespoň některá z árií je shodná s áriemi v inventáři sign. G 28a, nespecifické názvy jako „aria de tempore, aria a canto solo“ znemožňují říci, že se jedná o shodné skladby. Přikláníme se však k názoru, že se jedná o zcela odlišné kompozice než ty, které byly zaznamenány v předchozím inventáři.

Mezi skladatelskými jmény zde nalézáme Antonia Caldaru, Giovanniho Battistu Bononciniho, Johanna Adolfa Hasseho, Giuseppe Porsilleho, Nicola Porporu, Antonia Bioniho, Giovannho Battistu Pergolesiho, z mladší generace Christopha Willibalda Glucka, Jana Václava Stamitze či Haydna. ${ }^{34} \mathrm{Z}$ domácích skladatelů je zde zastoupen Jan Josef Ignác Brentner, František Antonín Míča, oba Brixiové a další. Značné množství kompozic opět uvádí jako majitele Antonína Jana Ignáce Krimera, př́ípadně jeho syna. Současně se zde ovšem nacházejí i záznamy Weiserových skladeb z počátku 18. století, například Aria de Confessore, quocunque Sancto vel Sancta. ${ }^{35}$ Zcela nezodpovězenou otázkou je v tuto chvíli osud těchto hudebnin již v době vzniku inventáře. Dva obsahově různé inventáře naznačují, že hudebniny byly bud' umístěny na jiných místech, nebo bylo plánováno jejich přesunutí jinam. To by odpovídalo faktu, že se z inventáře sign. G 28b dosud neobjevila žádná hudebnina. Můžeme doufat, že by některé z nich mohly být v budoucnu nalezeny v rámci jiných sbírek.

\section{Závěr}

Průzkum uvedených inventářů včetně jejich srovnání s dochovanými hudebninami z kostela sv. Bartoloměje v Blí̌kovicích umožňuje seznámit se s téměř kompletním obrazem zdejšího používaného hudebního materiálu v průběhu 18. století, který byl na takto malou lokalitu velmi bohatý. Dnes dochované hudebniny uvádí jak nejstarší z inventářu sign. G 28a, tak naopak nejmladší sign. G 28c. V tuto chvíli není možné dohledat žádnou z hudebnin uvedených v inventáři sign. G 28b, tedy si tato studie klade za cíl být výcho-

32 Na titulním listu: „Ariae Pro Choro Lispicensi / imannatae / Ignatio Trnka Ludi et Chori Rectoris / 1789.“

33 Zřejmě se většinou bude jednat o kontrafakta.

34 Haydn je v inventáři uveden s křestním jménem Sigismundo. V tomto případě se jedná zřejmě o chybně pochopenou a rozepsanou zkratku „Sig.“ pro Signor. Blíže nelze určit, o kterého z Haydnů se jedná.

35 Inventář G 28b, s. 4, č. 72. 
zím bodem pro další výzkum v rámci daného tématu. Pozornost si zaslouží také životní osudy všech zdejších kantorů a majitelů hudebnin.

\section{Bibliography}

\section{Sources}

Oddělení dějin hudby Moravského zemského muzea (ODH MZM), Inventář, signatura G 28a, provenience Blížkovice.

ODH MZM, Inventář, signatura G 28b, provenience Blížkovice.

ODH MZM, Inventář, signatura G 28c, provenience Blížkovice.

Moravský zemské archiv (MZA) Brno, E 67, sign. 13415, s. 203.

MZA Brno, E 67, sign. 10660, s. 162.

MZA Brno, E 67, sign. 10660, s. 358.

\section{Literature}

BERKOVEC, Jiří. České pastorely. Praha: Supraphon, 1987.

HLAVÁČEK, Petr. Kantoři na Moravě a ve Slezsku. Online databáze. Dostupné z: http://cantores. wz.cz/

KOURKOVÁ, Lucie. Pamětni kniha městečka Brtnice z 18. století. Diplomová práce. Jihočeská univerzita v Českých Budějovicích, vedoucí práce doc. PhDr. Josef Hrdlička, Ph.D., 2011.

MALÝ, František. Blížkovická hudební sbírka. Časopis moravského muzea, roč. 70, 1985, s. 201-210.

PADRNOSOVÁ, Jitka. Školství. In NEKUDA, Vladimír. Moravskobudějovicko, Jemnicko. Brno: Muzejní a vlastivědná společnost v Brně, Brno, 1997.

RACEK, Jan. Hudební inventáře a jejich význam pro hudebněhistorické bádání. Časopis moravského musea. Vědy Společenské, roč. 47, 1962, s. 135-162.

SEHNAL, Jiří - VYSLOUŽIL, Jiří. Dějiny hudby na Moravě. Brno: Muzejní a vlastivědná společnost v Brně, 2001.

SEHNAL, Jiří. Kantorská hudba na Moravském Slovácku v 17. a 18. století. Slovácko, 1962-3, s. 124.

ŠTĚDROŇ, Bohumír. Krimer. In ČERNUŠÁK Gracian - ŠTĚDROŇ, Bohumír - NOVÁČEK, Zdenko. ČSHS. Praha: Státní hudební nakladatelství, 1963, s. 750.

TROJAN, Jan. Kantoři na Moravě a jejich hudební aktivita v 18. a 19. století. In Sbornik praci Filosofické fakulty brněnské univerzity, 1984-1985, roč. 33-34, č. H 19-20, s. 113-118.

TROJAN, Jan. Kantoři na Moravě a ve Slezsku. Brno: Muzejní a vlastivědná společnost v Brně, 2000.

Toto dílo Ize užít v souladu s licenčními podmínkami Creative Commons BY-SA 4.0 International (https://creativecommons.org/licenses/by-sa/4.0/legalcode). Uvedené se nevztahuje na díla či prvky (např. obrazovou či fotografickou dokumentaci), které jsou v díle užity na základě smluvní licence nebo výjimky či omezení příslušných práv. 